\title{
Looking at Feminist Pedagogies: \\ What is Seen in the Literature and What is Seen in an Art Education Studio/Classroom
}

\section{Carole Woodlock}

\begin{abstract}
Ferminist Pedagogy is about teaching in a particular way: recognizing the relations of power-based on gender, class, race and sexual orientation - that permeate the classroom. It is influenced by the emphasis of the women's liberation movement on 'process' and accepts the intrinsic link between changing curricula and changing teaching practice. In this sense, feminist pedagogy is about validating the process of teaching... Ferninist pedagogy make visible the real experience of gender in society, in the school and in the classroom. It unmasks the dynamic of power/powerlessness, the devaluation of women and the invisibility of their experience (Briskin. 1990, p.1).
\end{abstract}

\section{Some Origins of Feminist Pedagogy}

In 1977 an issue of Studies in Art Education was dedicated to the research and theory on gender differences in art and art education. In that issue Georgia Collins presented a way to think about difierences between masculine and feminine approaches to making and teaching art in education. Collins emphasized rethinking 'our' views on the objectives of art education. She considered the focus on "holistic and coherent" views as overly simple. To accomplish a more complex and fulfilling inquiry she proposed "an androgynous model for art education". This model would move away from oppositional stances such as theory versus practice, and masculine versus ferninine. It would incorporate qualities "in a manner whereby these principles, although equal in relation to each other take on a higher value when submerged in a whole which ideally achieves their harmonious integration" (Collins, 1977 p. 54). In 1981 Collins took her model further, exploring possibilities for three approaches to teaching in art education: the integrationist, the separatist and the pluralist. Three years later in Women, Art, and Education Georgia Collins and Renee Sandell outlined a wide range of issues related to women's art education, particularly historical and social. From these inquiries, Collins and Sandell established a base for a dialogue on feminist pedagogy in art education.

Renee Sandell wrote about the need for and the possibilities of, a feminist art education in her 1978 doctoral dissertation, Feminist Art Education: Definition, Assessment and Application to 
Contemporary Art Education. In this she defines a feminist art education as being "conceptually, as well as literally, a hybrid between ieminism (an ideology) and art education (theory and practice)...Art education relers to both the educating of artists and education of people about art and its relationship to society. Feminism applied to art education refers to the process of educating an artist via feminism, or education about feminism via art" (Sandell, 1978, p. 7). Sandell's and Collins' inquiries, and the many others form an armature for feminist pedagogies, where feminism as theory and feminism as action engage in dialogue and form modes of inquiry to be explored in the teaching and learning experience.

\section{Defining Feminist Pedagogy}

Sandell, in a more recent article, defines feminist pedagogy "as ultimately seek(ing) a transformation of the acaderny" (Sandell, 1991). That transiormation occurs when teachers and students create "classroom interactions that foster empowerment, community, and leadership" (Sandell, 1991 , p. 181). She sees feminist pedagogy as an "alternative instructional model" towards "shap(ing) and inform(ing) the processes of art teaching and learning" (Sandell, 1991, p. 180).

How would one actualize this alternate model within the parameters of the teaching and learning site? To begin, I would want to generate a teaching philosophy which defines feminist pedagogy, as it pertains to my vision of teaching and learning. Then I would engage with students in such a way that this teaching philosophy, over time and after reflecting on the interactions in the studio classroom, became a 'reality'. The circular nature of this process would intorm the teaching and learning site.

\section{Forming a Teaching Philosophy}

As Briskin stated in the opening quote, feminist pedagogy is "about teaching a particular way". Feminist pedagogy is a teaching process that focuses on power relationships in the studio/classroom. This teaching process is specific to the context of the actions. That context is the studio/classroom and its surroundings. Magda Lewis, a teacher of sociology in Ontario, describes her teaching process:

The challenge of feminist teaching lies for me in the specifics of how $I$ approach the classroom. By reflecting on my own teaching, I fuse content and practice, politicizing them both through feminist theory and living them both concretely rather than treating them abstractly (Lewis, 1992, p. 187). 
The main goal of my teaching process is to provide an environment that empowers the student and the teacher. To do this I use a self-reflective process that Lewis practices. Of great importance to me is the fusing of content and practice in the context of learning and teaching about issues in education, also one of Lewis' objectives.

In my teaching process I have three points of reference: the student learning process, the action process and the unveiling of reflection process. The main goal in moving between these points of reference is for the student and teacher to become aware of their position and actions within the learning process in art education. This will better enable them to act and understand their actions in the future, in the studio/classroom or in another setting outside of the educational institution. I will briefly describe each of these points.

\section{The Student Learning Process}

In setting a tone for the studio classroom environment, a foundation of the curriculum is presented. How I set the tone depends upon the content of the course and the students involved. I start the course with a project that accentuates the focus of shared learning. I also present a format for the class that makes room for everyone's voice. This project establishes the essence of the curriculum. The essence is that each individual moves towards defining their personal processes of making and discussing art work in relation to being a member of a community.

Skills are introduced when the students need them. When a student articulates that they feel their "needs" require redefining, they must communicate to me in such a way that I can take up an authoritative role to assist them in acquiring further skills to fulfill those specific needs. This pattern of communication is established and negotiated by the student and myself at the beginning of the course, and throughout the year it is clarified.

\section{Action}

I give the students a struclure for three things: self-reflection, response through dialogue, and awareness of time as it relates to the process of self reflection and dialogue in activities inside and outside the studio classroom. Once the students have moved through this structure, they can initiate actions in the "Action Process": they can enact upon their process of making art, talking about art, teaching art, and listening to it through their own words. The students are empowered in the "Action Process," through the actualization of the reflective process. 
Moving irom a stance of being the object within the process, to a subject in relation to the process is a key transition within this point of relerence.

Using theory we can understand how an individual can move from the position of object to subject, and we can understand the importance of this move. We can also bring this understanding to our creating and viewing of artwork... These links between theory and lived experiences are reciprocal, each in tum replenishing and strengthening the other (Garber \& Gaudelius, 1992, p. 20).

\section{Unveiling of the Reflection}

Placing the whole process in context and perspective is the third point of reference in my teaching process, and it's the first step towards the development of the philosophy of the individual student. Once the students have reflected upon the process, I can then assist them further by speaking about the evolution of their learning. This is where we unveil our process, deconstructing and reconstructing our curriculum. One objective of this unveiling is to clarify details within my curriculum and their curriculum, making both visible. This occurs when the group responds to art work made by one another. It also occurs in their rellections through writing, and through verbal dialogue with me.

As the students grow in their ability to reflect and communicate, they are able to locate their actions and $m y$ actions. The students vocalize how these multiple "actions" belong to all of us as a group, while they are distinctly experienced by the individual.

In recognizing the need for student empowerment through a melding of the aflective and cognitive experience of a subject, feminist pedagogy also deals with the art educator's concern for human development through artistic enablement...(it) can offer an interactive process model for art instruction that address(es) the continuing needs for raising not only the status of women, but also for artistically empowering all individuals (Sandell, 1990. p. 185)

Three approaches identified by Collins, the integrationist, the separatist, and the pluralist help us understand how we might further define the above model of feminist pedagogy. 


\section{Integration, Separatism and Pluralism}

With feminist reform as the end product of each approach, Collins discusses what integrationist, separatist, and pluralist might mean to the practice of the art teacher who adopts such a mode. The integrationist art teacher views her students as equal with no regards to differences in sex. A neutrality is encouraged and the art teacher should be dedicated to the development of "sex-neutral skills, attitudes, and behaviors" in the studio classroom.

Nevertheless, explicit problems for women must be confronted in the art classroom and given full discussion... The prejudicial use of the notion of feminine sensibility in its arbitrary and unwarranted attachment to the female and her art would be examined and debunked (Collins, 1981, p. 88-89)

The separatist art teacher expects and sees the "differences in interests, skills, and attitudes" (Collins, 1981, p. 90) according to gender. The art teacher should approach each individual student according to their gender.

The separatist approach to art education will be extremely critical of traditional values attached to certain subject matters, styles, media, and life-styles in the art establishment...processes that have been devalued because of their feminine association need to be attended to with more respect...Support needs to be given female students as they explore personal experience and values in search for modes of expression (Collins, 1981, p. 90).

The pluralist art teacher has components of both the integrationist and the separatist. She believes that gender differences are important to take into account, but she also believes the polarization of the two are unacceptable. The pluralist encourages the growth of the individual's sensibility and expression through engendering a balance between masculine and feminine awareness. Variety of interests and expression that generate from the individual are the goals of the pluralist art teacher.

The pluralist ant teacher, according to conscience and personal vision, might engage in remedial education for all art students to the end that they develop a full range of previously gender-identified skills, attitudes, and interests. Or the pluralist art teacher, fearing that the model of androgynous sensibility imposed on all art students would reduce variety in art, might seek to develop existing 
sensibilities and a tolerance and appreciation of differences (Collins, 1981, p. 91).

Collins proposes that as teachers and learners we should engage publicly, in our classrooms, with our students, with these three approaches.

\section{A PIuralistic Feminist Pedagogy}

A teaching philosophy that has a feminist focus is a feminist pedagogy. Social change is one of the main issues in feminist theory, and ferninist pedagogy is a mode one can invoke as a way to enact change in the art education studio/classroom. "All educators will find ferminist pedagogy useful because through it they can address the issues of social change" (Sandell, 1991, p. 183).

Through the consideration of content and pedagogy with a ferminist focus the teacher of art can promote a learning site that empowers both the teacher and student. Meaning is made inside the classroom and the teacher has great influence on / upon / with, her students. Using a feminist pedagogical approach the teacher of art could foster individually centered meaning-making. This would be a great value to the formation of student knowledge and experiences as well to the learning and experiences of the teacher (Weiler, 1988).

As teachers we must allow ourselves to escape the confines of (our) position for it is only when we do so that our students can exist in our classrooms as subjects. We must be prepared to give up some of our power. As teachers, we must no longer desire to be the masters of the discourse (Garber \& Gaudelius, 1992, p. 27).

Feminist Pedagogy gives us a chance to pull away from, broaden and destroy the assumed 'norms' and 'stereotypes' regarding not only gender, but race and class, within the learning site (Briskin 1990. Sandell 1991). Through the actualization of this pedagogy one can become visible and empowered, not from an outside act or voice, but from within and from one's own actions and understanding. Fostering multiple modes of understanding is vital to this organic process of teaching from a ferninist perspective. 


\section{References}

Briskin, Linda. (1990). Feminist Pedagogy: Teaching and Learning Liberation. Ontario: CRIA/ICEF.

Collins, Georgia. (1977). Considering an Androgynous Model for Art Education. Studies in Art Education, 1 8(2), 54-62.

Collins, Georgia. (1981). Feminist Approaches to Art Education. The Journal of Aesthetic Education, 1 5(2), 83-94.

Collins, Georgia \& Sandell, Renee. (1984). Women, Art and Education. Virginia: National Art Education Association.

Garber, Elizabeth and Gaudelius, Yvonne. (1992). Object into Subject: Feminism, Art Education and the Construction of the Self. Canadian Review of Art Education, 1 9(1), 12-33.

Lewis, Magda. (1992). Interrupting Patriarchy: Politics, Resistance and Transformation in the Feminist Classroom. In Carmen Luke \& Jennifer Gore (Eds.), Feminisms and Critical Pedagogy (pp. 167-191) New York: Routledge.

Sandell, Renee. (1978). Feminist Art Education: Definition, Assessment and Applications to Contemporary Art Education. Dissertation. Ohio State University, UMI: 7819659.

Sandell, Renee. (1991). The Liberating Relevance of Feminist Pedagogy. Studies in Art Education, 32(3), 181.

Sandell, Renee. (1977). Studies in Art Education: A Journal of Issues and Research in Art Education, 18(2), 54-62.

Weiler, Kathleen. (1988). Women Teaching for Change: Gender, Class and Power. New York: Bergin and Garvey Publishers. 